\title{
Female truck driver: a journey of gender, work, and identity discussions
}

JULice SALVAGNI ${ }^{1}$

${ }^{1}$ Universidade Federal do Rio Grande do Sul (UFRGS) / Escola de Administração, Porto Alegre - RS, BrazIL

\begin{abstract}
This study looks at female truck drivers who, besides being truck drivers, choose to work the long routes. The problem of gender identity in the workplace was addressed by analyzing the female truck driver, considering she performs an itinerant activity. Riding along is a constituent part of this ethnographic research, which aims at the researcher's active participation in the female trucker's journeys and the participation of the female truck drivers as a voice to be heard over this reality. Identity is seen from the notion of identity, difference and différance in order to see the female truck drivers' reality connected with their itinerant routine. Gender in the workplace is handled from the legitimation formats of social roles and identities, which are solidified nowadays, especially from the point of view of the feminist critique of sex biology. This critique deconstructs the myth of supposed physical strength advantage. An understanding of non-places was used to address the transience quality of occupation since the results point to the development of a marginal identity. We approach the work through the understanding of hierarchies, the powers, and the sexist division of labor proposed, where motherhood is emphasized as the main obstacle for female truck drivers to continue their occupations. At last, it is pointed out that although women are conquering new workspaces, hierarchical and power relations are reorganized within the institutions, creating new gender relations, but remaining unequal.
\end{abstract}

Keywords: Female truck drivers. Work. Gender. Identity. Non-places.

\section{As caminhoneiras: uma carona nas discussões de gênero, trabalho e identidade}

\section{Resumo}

Este estudo considera caminhoneira a mulher que, para além de ser motorista de caminhão, opta por trabalhar com rotas longas. Desenvolvemos a problemática da elaboração da identidade de gênero no trabalho por parte da caminhoneira, especialmente do ponto de vista das características de uma atividade itinerante. A carona faz parte de uma pesquisa etnográfica, que visa à participação ativa da pesquisadora nas viagens da caminhoneira e das caminhoneiras enquanto locutoras dessa realidade. A identidade é vista a partir da noção de identificação, diferença e différance, a fim de pensar a realidade da caminhoneira de modo articulado com sua rotina itinerante. Gênero no trabalho trata dos formatos de legitimação dos papéis e identidades sociais solidificados na atualidade, sobretudo do ponto de vista da crítica feminista à biologia do sexo, que desconstrói o mito de suposta vantagem de força física. A compreensão de não lugares trata da transitoriedade característica da ocupação, já que os resultados apontam o desenrolar de uma identidade de fronteira. Abordamos o trabalho por meio do entendimento das hierarquias, dos poderes e da divisão sexista do trabalho, onde enfatizamos a maternidade como principal entrave à continuidade da mulher na atividade de caminhoneira. Por fim, destacamos que, embora a mulher esteja conquistando novos espaços de trabalho, as relações hierárquicas e de poder se reorganizam no interior das instituições, criando novas relações de gênero, mas não menos desiguais.

Palavras-chave: Caminhoneiras. Trabalho. Gênero. Identidade. Não lugares.

\section{Las camioneras: un viaje por las discusiones de género, trabajo e identidad}

\begin{abstract}
Resumen
Este estudio considera 'camionera' a la mujer que, además de ser conductora de camiones, opta por trabajar con rutas largas. Desarrollamos la problemática de la elaboración de la identidad de género en el trabajo por parte de la camionera, especialmente desde el punto de vista de las características de una actividad itinerante. Carona (autostop) forma parte de una investigación etnográfica, que tiene como objetivo la participación activa de la investigadora en los viajes de las camioneras y de las camioneras como locutoras de esa realidad. La identidad es vista desde la noción de identificación, diferencia y différance, a los efectos de pensar la realidad de la camionera de manera articulada con su rutina itinerante. El género en el trabajo trata de los formatos de legitimación de los roles e identidades sociales solidificados en la actualidad, especialmente desde el punto de vista de la crítica feminista a la biología del sexo, que deconstruye el mito de la supuesta ventaja de la fuerza física. La comprensión de los no lugares aborda la transitoriedad característica de la ocupación, ya que los resultados apuntan al desarrollo de una identidad fronteriza. Enfocamos el trabajo a través de una comprensión de las jerarquías, los poderes y la división sexista del trabajo, donde enfatizamos la maternidad como el principal obstáculo para la continuidad de la mujer en la actividad de camionera. Finalmente, enfatizamos que, aunque la mujer esté conquistando nuevos espacios de trabajo, las relaciones jerárquicas y de poder se reorganizan dentro de las instituciones, creando nuevas relaciones de género, pero no menos desiguales.
\end{abstract}

Palabras clave: Camioneras. Trabajo. Género. Identidad. No lugares. 


\section{INTRODUCTION}

Women truck drivers theme brings, together with the discussions on work and gender, in these interlocutions the identity elements that derive from social roles that integrate a performative and political action, substantially. Thus, the truck driver is who will guide a theoretical construction regarding the course of the sociological loom given to the overlapping of these punctuated aspects and, likewise, these are the women who, in their individualities, help to write a narrative of their own lives, of their itineraries.

Taking a ride in the hitchhiker, in the language of the road, means to be part of the truck driver's journey, to take a ride, since in popular language the hitch expresses the space of the truck, either in the cabin or in the bucket, where road travelers can plead a temporary vacancy for a sometimes uncertain destination. In this sense, we nicknamed the woman a truck driver who, besides being a truck driver, chose to work with long routes and due to this, spend a long time on the road. This specificity of work practice is recognized by offering greater credibility to workers and, consequently, higher remuneration. For that, drivers who intend to travel great distances may stay on the road for at least 30 to 40 days, sleeping and feeding on the truck itself. For this reason, the truck drivers explain that, among other reasons, it is an activity still little exercised by women with the aggravation of being a work marked by informality (ANTUNES, 2008, 2011). The hitchhiking is the central constituent part of the research corpus, which aims at the active participation of the researcher in one of the trips of the truck driver and the participation of truck drivers as announcers of this reality to be discovered, which is characteristic of ethnography. The woman at the wheel who, in the popular saying represents a "threat of constant danger", is for our research the object of study.

The choice of an ethnography based on Augé $(1994,1999)$ allows us to problematize the activity of the truck driver together with the worker and her colleagues by revealing, through the translation procedure, inherent elements in the power relationships that may exist in a possibly invisible universe. Fourteen women truck drivers, 3 men truck drivers (husbands) and 22 interviews were made during the 3 years of data collection (2012-2014). The construction of this narrative, made up of verbal and imagery discourses, made it possible to visualize in depth the aspects inherent to the work of the truck driver and the theoretical questions. We adopted the content analysis proposed by Laurence Bardin (1995), one of the tools that allow us to understand semantically - or relative to the meaning of what comes from the talk of truck drivers.

The possibility of helping to write about the variations of the norm seems to us a real and emerging challenge to the present time, even though it is inevitable to create new norms in naming them. Contemporaneousness, which is that same society that bubbles through a differentiated condition in the ways of being, also shows its faces in claiming some control in the "uncontrol" of normative matrices, suggesting that the debate, although it is on the table, is far from being locked up. Thus, the sexual division of labor, which unequally affected female and male employment, attributes to men the productive function that has a strong aggregate social value, while women are socially associated with the reproductive function (HIRATA, 2003; KERGOAT, 2009).

The aim of this research was therefore to identify the elaboration of the gender identity and the work of the truck driver, which allows for the detailed sociopsychological compression of the social processes that are established with it (and from it) masculinized labor relations. To this end, we seek to identify the work routine of the truck drivers coming from the narratives, observing the daily actions of gender and work, through the truck follower in their workday, either at the place of loading, maintenance of the vehicle or even in the course itself.

\section{LABOR IDENTITY AND GENDER PERFORMANCE}

Considering the identity as an intrinsical concept related to work, we understand that the subject is transformed through social relations and at the same time is a transforming agent of the social institutions with which it is implied. We note, however, that although this immersion in the work seems to be daring - and to some extent, it is - there is a level of performance that gradually makes the characters are framed by caricatures that belong to the same previous molds established from relations of power built and solidified historically and socially. In general, we affirm an identity change that is "fragmenting the cultural landscapes of class, gender, sexuality, ethnicity, race, and nationality that in the past had given us solid locations as social 
individuals" (HALL, 2000a, p. 9). Moreover, especially in relation to work, the concept of "identity" requires in-depth studies that emerge meaningful provocations between what is produced in relationships from the mirror of otherness.

Thus, différance not only gives voice to what is different within a relationship where identity is established but still proposes that there is no qualitative valuation between what serves as a parameter for the composition of a hybrid space in relation to the other (HALL, 2003). In establishing this proposition, embedded in the proposition of variable meaning, it is possible not only to think of the transformation of meanings over time and in different cultures but to consider that this meaning will never be given without it being properly inserted in context at any given time. Taking the debate to the discussion of gender identity, inserting woman into a masculine activity makes her different not only within her environment that is mostly masculine but also for her other social relations since in these cases she is not considered as a woman whose work choice is conventional.

As a central point in the discussion, the need to discover the identities in these relations, especially the work-gender scope through the narratives that outline a performatization movement, which consists in the staging of a social identity that this woman considers appropriate (or not) for a given situation. We argue that if, on the one hand, theorizations need to account for an ephemeral contingent of diversities on the other, and within that contingent, everyday life is merging references of subversion with highly conservative spaces that may be predominant, but whose logic of adequacy follows the reference to the current social norm. Based on this historically constructed normalization, even what is considered subversive is gradually being incorporated (or perform) by the own notion of the norm, not only to gender issues but also to discussions about work.

The women truck drivers often talk about these issues. All, at least at some point in the hitchhiker's talk, mention that someone, usually close to them, that did challenge the ability of the women on doing this activity. After some time, the social and familiar notion of those who are around it goes from the ridiculous to the accepted, from the task that was impossible to the brave. That is, an identification and, consequently, identity formation comes from the models demanded by the work in relation to the binary forms of gender and sexuality, evidently always contingent. In the case of truck drivers, the job opportunity was given them much by a demand of the organization properly familiar, since in all the narratives there is a man, father or husband, opening the door of the truck for the woman to work, usually without dissociating the bond hierarchical relationship.

The overlapping of work and gender is indisputable with regard to the elaboration of identity, but what is interesting is the emphasis on a gender identity produced and reinforced by and at work, by dimensions of power inherent to the capitalist and production model. For this, it is commonplace to displace the social role of the woman that induces her to perform a masculine identity, or an identification, in order to be accepted and respected in her workspace, which does not occur in other activities.

Hall (2000b, p. 106) understands identification as "a construction, as a process never completed - as something always 'in process'". In contrast to what is established in common sense, identification as the recognition of equals, identification "operates through différance, it involves a discursive work, the closing and marking of symbolic boundaries, the production of 'border effects' (HALL, 2000b, p. 106). The identifications can meet the identity of the subject or differentiate it completely. In this act of recognizing the identity is being created, and this creation makes the production of identifications which is not something logical and determined. Identity being "perceived as a complex construct, multifaceted and subject to temporal contingencies" (CARRIERI, PAULA and DAVEL, 2018), can, therefore, be permanently transformed. By this conception, the study of identity presupposes an accurate observation of the social and the environment where the person is inserted, as a space of producing symbolic material. In this case, we consider work as a fundamental source for the production of gender identities.

Work is still an institution that purposely modifies subjects to conform to their solid, "correct", binary and heteronormative models. We bring to the surface this debate to provoke noise in the stability constituted and solidified in what is supposed to be the identity of work and gender in the contemporaneity; is a political way of weaving sociological theory, which may reflect directly on the work of truck drivers or other women in professions considered masculinized.

These theories advance and do not detract from the structuralist, especially Marxist, understandings of social relations. For example, we can not say that the processes of class domination, based on economic exploitation, are extinct or overcome; in fact, they remain more salient and painful than ever (SILVA, 2011). Even if post-structuralism points to the globalizing character of the economic inequalities of power relations that are everywhere, it is inevitable to point out that "some forms of power are visibly more dangerous and threatening than others" (SILVA, 2011, p. 147). Summing up, we work much more with the idea of complementarity from one current to the other than from that of any form of alternation between them. This premise helps to think the different theoretical currents in dialogue, in order to elucidate the spectrum of relations between work and gender without succumbing to a single theoretical or even temporal appreciation. 
A "displaced structure" can be visualized in addressing the fragmentation in postmodernity, one in which the center is displaced, not replaced by another, but by a 'plurality of centers of power'" (HALL, 2000a, p. 16). Identity is the formation of multiple forms of being that overlap and do not eliminate one or the other and are constantly determined by social relations. These contemporary relations of multiple and overlapping forms of identity allow for the rise of work as masculinized, for example, as well as the most different family configurations that break with the traditional one in its consecrated assignments to gender roles. In the case of truck drivers, there is a historical and social construction inviting the transgressions of social roles, where other identities are gaining some space to transit, although possibly stereotyped.

These theoretical locutions are fundamental to think about the construction of a politics of identity or, in this case, of postidentity. Among the disputes about the moral meaning of identity, Louro (2008) points out that, while some indicate the deviant character, abnormality or inferiority, others proclaim normality or naturalness, but all seem to agree to be a "type" human. The proposal of a post-identity policy challenges us to think that a sociological understanding of gender identity in the work will be possible from the translation of this role, in the most theatrical and interpretative sense of the term, to show that, although discourses are transgressors, they, paradoxically, are framed in a scene of social relations that condemns them to a new order of submission; that is, another way of experiencing a gender identity at work has been possible, although it remains qualified as falling short if observed in a context of dominant masculine identity.

Although identity is not possible to be framed or to frame it is fixed conceptually and intentionally to the notion of incompleteness and inclusion. However, it would be inconsistent not to consider the appropriateness attributed to gender and work identity in the narratives of everyday life. To deal only with the theoretical opening of concepts, without starting from the abrupt and prejudiced demarcations that the phenomena gain in the daily contours, only produces a theorization sufficiently distant and short of the social relations, therefore, equally distant of a politics of post-identity. Thus, we propose, in the same way, a certain flexibility of post-structural feminist discourses, in order to promote an articulation with the concepts of work in its most varied senses.

With this legitimate premise, Scott (2005, p. 12) states that "recognizing and maintaining a necessary tension between equality and difference, between individual rights and group identities, is what enables us to find better and more democratic outcomes." That is, the treatment of these issues itself already causes that the discussions remain lit and the current transformations, even in inexpressive measures. It is important to notice that, first and foremost, the inherent conflict in the search for individual and group rights, as well as in the attempt to operationalize equalities with respect to differences. This means that there is a social construction reinforced enough to be maintained, at least until it begins to be locally questioned, even though individually, within small groups, analogous to what happens with the entry of the woman into the truck activity. Therefore, "equality is an absolute principle and a historically contingent practice. It is not the absence or elimination of difference, but the recognition of difference and the decision to ignore it or to take it into account "(SCOTT, 2005, p. 15).

In this contingent of differences, the identities are created with an evaluative perspective, that is, qualitative of the differences, but in which are individually the premises that contemplate the organizations of the groups. The tensions regarding the work of the female truck drivers are placed and relocated as each woman starts to exercise the activity and consolidate a new form of relationship between the people of that group. This is visible in a truck driver's speech when he claims to have been targeted by the group for traveling with a woman and therefore not enjoying the festivities involving prostitutes, for example, which would point, according to this logic, a forbidden space to the woman. What we perceive, in order that the activity of women, in this case, has been possible, is not only that there a displacement of the feminine identity, which happens to occupy a masculine activity, but also the role of the man who openly include the woman in a forbidden environment, individually re-signifies, and in the relation, either with the wife or with the other colleagues, an aspect of her identification.

While there is a twist of gender roles with the entry of women into spaces that were considered masculine, we still consider this relationship as part of a power that continues to operate within the logic of gender. But is it not possible to list some significant changes, even within a power that does not cease to operate by binary logic? Considering the activity of the truck drivers as a possible affront to the dominant status of male power, it is important not only to reveal the own trajectories of this identity reorganization but also to demonstrate the social and historical importance of these disturbances of the notions of gender, especially with regard to the field empirical in question.

If we think about what gender discussions still demand and what feminist theories have been proposing as an interpretation of gender problems, this aspect might seem almost irrelevant, given the emphasis that studies give to the effectively nameless 
processes present in this composition. However, we work with the idea that these interferences in the normality of gender, even if "subtle", are capable of producing real and significant changes in the realities observed.

The fixation of the materiality of sex is what would give few exits to the very transformation of the understanding of gender throughout history since the very notion of gender would have a discursive limit especially related to the materializing conception of the body through the sex. This approach is especially interesting, since it does not deny the dialectic of the relation of the understanding of "sex" and "gender", but, at the same time, expands it significantly, since it assumes the limits of this notion of correlation, it questions the possibilities of extending these limits and the consequent effect that this enlargement would have on the concept or, rather, on the conception of identity in the social.

This conflict is explicit in what we seek to highlight, as a gender discussion, of the elaboration of an identity that is intermediated by a masculinized and, in this case, also itinerant work. In the meantime, we go through theoretical and empirical instances, observing subjective, constructed and reconstructed aspects of social codes, therefore, collective ones that, in turn, are crossed by different hierarchical spheres in the relations of power.

We understand that the construction of gender is independent of sex, although biological identification still seems to us an indicator, even if the socially constructed appropriation of this correlation is taken into account. Nicholson (2000, p. 2) launches some epistemological perspectives, stating "if the body itself is always seen through a social interpretation, then 'sex' cannot be independent of 'gender'; rather, sex in that sense must be something that can be subsumed by gender. "This makes the debate delicate because, paradoxically, the subtlety of these distinctions cannot be decisive, but neither can it be disregarded. That is, "it is because of a certain prior disassociation between biology and socialization that, at a very basic level, many of us are who we are" (Nicholsson, 2000: p. 20). In this sense, for the author, "even when the culture itself associates gender with biology, a feminist analysis that follows these presuppositions is incapable of explaining those who deviate from the norm" (Nicholson, 2000, p. 21).

We consider that with female truckers assuming for themselves a profession whose masculinized stigma still predominates, it means that one is willing, in some way, to be recognized by this profession whose link with the masculinized, grotesque or sexist environment is almost immediate, even if coming from common sense cuts. We consider the entry into this profession still a significant fact to women, especially from the point of view of the relation of this profession with an identity that supposes some transgression before the dual prerogatives of gender in the society. Thus, gender would be "the mechanism by which the notions of the masculine and feminine are produced and naturalized, but also as the mechanism by which these terms are deconstructed and denatured" (PISCITELLI, 2008, p. 265).

Considering the difference as a social relation, Brah (2006: p. 362) understands that "it refers to the way in which difference is constituted and organized in systematic relations through economic, cultural and political discourses and institutional practices. This means that it emphasizes the systematicity through contingencies." This process of relationalities among the subjective contingents of the construction of identity is what allows the redoing of individuals and collectives that unite and overlap in the constitution of society.

On the biological discussion of sex and the consequent configuration of gender, Hird (2004) provokes the discussion around sexism from the scientific constructions on the differences of the body. The research focuses on theories that refer to the controls of "sins" of "deviant bodies" and produce polished degenerations to the sexist oppression defended and dissolved by religions or the media. The focus is "on the critical-feminist analysis that can be termed the 'essence' of 'sexual difference' (HIRD, 2004, p. 30), where 'essence' is understood as the structure of the skeleton, gonads, hormones, chromosomes, and genes, which is related to the way in which sexual division, sex and sexuality will be based on scientific knowledge bases. The author deconstructs the bases of scientific knowledge claiming limits to the parameters of it. In this sense, the feminist critique points out significant methodological problems that are epistemologically limited in the composition of social construction to support these arguments.

For the reality of the female truck drivers, the debate around in the body is fundamental so that we can at least produce a dissonant voice before the socially known maxims on the fragility of the woman's body. When the theme of the female truck drivers is raised, many say that they only entered this segment thanks to the recent technology used in trucks, which makes the work lighter. It is clear that this argument can only be used to justify women's inferiority in the labor market since in practice there are many reports of women driving manual trucks even though their husbands have automatic trucks. The argument discursively reduces the capacity of women and is built on the premise of the physical differences of bodies. 
Hird (2004) reviews studied that addressed the female skeleton that points to a weaker structure, intended for the breastfeeding of children, whose crooked structure and tender belly would place women, according to this scientific model, as inferior to men. In addition, studies on the skull demonstrate that the female organ is smaller and wider, suggesting some type of incomplete development. In view of this, the author emphasizes the scientific construction based on differences and that exalts the masculine body to the condition of superiority.

The deconstruction of the physical aspects helps us to think of the socially attributed assumptions of the woman truck driver who allocate her in a position of inferiority to the man, taking into account the aspects of the body. Based on these feminist studies, which question the emphasis that the medical and biological sciences studies suggest to the differences of the body, we understand that the woman is as capable as the man to carry out any type of activity at work, although it has a demand of physical strength. That is, the natural is not to be different, even when observed the man from the point of view of the species, since what changes is the social construction made over the years in order to demarcate the gender associations that direct the woman to occupy a place of inferiority.

\section{ITINERARIES OF IDENTITY: A RELATIVE DIRECTION}

To understand the dynamics of travel, we start from the concept of places and non-places developed by Augé (1994). The author understands places as "a set of elements, coexisting within a certain order, and space as the animation of these places, by the displacement of a driving force" (AUGÉ, 1994, p. 75) and describes at least three characteristics of place definitions which are useful to us in particular in order to delimit the frontier location which the itinerary causes and hence the definition of non-places. However, there is a margin between the concepts of places and non-places that makes these spaces coexist, especially in the contemporary world with their volatilities. Place and non-place are "fugitive polarities: the former is never completely erased and the latter is never fully realized" (AUGÉ, 1994, p. 74). However, above all, it is in the figure of the traveler and his itinerary that he lives the greatest archetype of non-places since the movement of subjects and their lack of references to a given space make up, in essence, the non-place.

For Augé (1994, p. 99), "the character is at home when he is at ease in the rhetoric of the people with whom he shares his life. The sign that you are at home is that you can make yourself understood without much trouble "; that is, to be at home, before having a house in the literal sense, constructed by walls, roof, and windows, one must feel comfortable enough that this space reaches, with an amplitude in the sensation of relaxation, identify where to be more if you want to be. In this reasoning, we consider that truckers, although well-adjusted and adapted to the truck, move part of their family, social and leisure life to another dimension, which is not that of work, perhaps not the home, but it is as if was a constituent of a parallel universe of construction of meaning that starts to be built in the course of the trip itself.

An itinerary is a line of a route, determined or not. In the case of the truck drivers, it is also a line of work, with a disciplinary system of production no less rigid than that of the assembly lines on the conveyors. For Canclini (1997), when we get to the word "line" we fall into a transit zone, which may evoke the situation of undocumented migrants, and we add to the discussion of travelers. This frontier space, which is the space of the road, of the road, of the condition of the movement, causes a broad specular invention of the cities themselves, a hybrid product in which the traveler assumes a central role. The itinerary, therefore, is "signposted by stages and strengths, composing with it a place of 'one-way' and a 'space"” (AUGÉ, 1994, p. 83). That is, however mobile the itinerary of the traveler is, however uncertain, relational and changing, yet there is an appropriation of meaning that occurs through "the coexistence of language, the signs of the landscape, the unformulated rules of the good to live, [since] it is the non-place that creates the shared identity of the passengers "(AUGÉ, 1994, p. 92).

The displacement of the activity causes her to emphasize the fact that she feels like a stranger when she returns to her own city. Not knowing where the room is, leads us to think of a dimension of space and time large enough to generate in the worker an impression of non-belonging. The others, in this case, are gradually distancing themselves from their own experiences of life and conceptions of the world, which are increasingly being compounded in the hitchhiker. This distinction, following Augé's (1994) conception, is imperative in the construction of identity and, therefore, the maximum index of the ways of relating to society in its most diverse strata, producing norms of identity patterns that suffocate and limit construction of meaning, 
individual and collective, that will be deviant from what is historically and culturally agreed by the dominant groups, where the academic institutions themselves are not discarded.

The female truckers, women that are in transit, represent in themselves the symbol of the abandonment of all that is unified. The subject who travels is himself "divided, fragmented and changing ... in such a way that only the movement is able to guarantee some equilibrium to the traveler" (LOURO, 2008, p. 13). This is significant, while it is important to walk, not to reach because the traveler never arrives. It is made up of paths, trajectories, and places, besides departures and arrivals.

Women, therefore, as they go first to the road and begin their journey in an environment that is considered to be the opposite of theirs, or rather, which determines not to be what they are, occupy a place (or non-place) which is the space of the nomad. This is the space of renunciation and deconstruction of any sense of identity, since they "refuse the fixity and definition of borders, and assume the inconstancy, transition and position" between "identities as intensifying desire" (LOURO, 2008, p. 21). Even when it comes to women entering the labor market, there is certain equality of treatment, wages, and opportunities, it makes it even more abstruse to identify the coercive forms that are produced in this relationship. The roles are also defined from the dual gender differences and create spaces of work that are typically adequate to their stereotypes.

When the subject does not adjust to the condition of the socially composed norm and if he cannot subvert it (or, at most, subverts it little), the social drama as proposed by the author becomes performaed. That is, "paper provides the standard by which the individual must act in the situation. Both in society and in the theater, the accuracy with which the roles give instructions to the actor will vary "(BERGER, 1978, p. 109). Disguise is a term that is especially interesting for us being able to represent, at the same time, the figuration of the social role and the discomfort of not being who we want, effectively. In another aspect, it is relevant to question the existence of a world, or even a scene, where there is no disguise at all. In other words, disguises seem important and even healthy to us if we use psychoanalytic prerogatives about possible defense mechanisms in the face of distressing situations; however, inevitably it seems to us that the evolutionary (but not necessarily evolved) course of society itself depends on the disclosures of the disguises, at least until the true face is transformed into a new disguise.

In the narrative of the female truck drivers, the proposition would be a kind of reformulation of the structures of work, of class, of society, much in the dialogue with the contemporary reformulations of gender that could not have been approached in this sense by Karl Marx, precisely because been part of the scenery of his time, too. In other words, the reappropriation of the social context - whose relevance here is in the expansion, rectification and incorporation of new elements - rather than a critique of structuralism is an attempt to rewrite the paths of power relations immersed in new meaningful codes, whose itself takes place in the expropriation of the very forms that labor acquires of the present time through the nuances that are in the means of production. Our intention, it should be pointed out, is very far from thinking about a new theoretical perspective, but at the most, to highlight dissonant and agreeing points of the theories reviewed for the purpose of understanding the phenomena inherent to the gender debate at work outlined here.

In time: there are concerns about the theoretical "moorings" which, if absent, could create some dangers to multiculturalism, as in the case of becoming binary precisely because it represents a universe of cultural questions that "not the dominant ones", being shown only as an opposing response to an already known truth. However, the constant notion of a movement about social readings, which do not deny the brutalities of economic and class realities, but deepen the debate from a point of view to broaden the discussion about subjects and their subjectivities, seems to us a path inevitable and pertinent to the need to dismantle certain labels without leaving them meaningless.

As for the work of the female truck driver, this is also justified today as being made possible only by the advancement of technology that is incorporated, especially, to the operation of the truck. If it were not for this technological advance, many say, the viability of women as truckers would not be possible, given the demand for the use of physical force to carry out the activity. This discourse, however, is deconstructed not only by the theories we address but by the very history of the participating women, since many drive a manual truck which therefore requires physical strength, unlike their husbands or colleagues driving automatic trucks. This shows that male labor and strength have no connection at all; on the contrary, only reinforces one of the many sexist discourses that have been (and are) historically constituents of the form of organization of labor which demarcates not only divisions but, above all, qualifications to male labor as being of any order of superiority and not domination. 
On the labor processes, the interference of the Taylorist and Fordist systems in the truckers' activity, which centralizes in their conception of the search for the economy of time tied to new labor management processes, is perceptible (NEFFA, 1998). References to this model can be perceived especially in the logic of the shortening of free time and in the attempt to accelerate still more the working time. The course to be followed is always measured for the shortest time. If one has succeeded, all the others will have to do at the same time, which helps to compose the violent scenario to which the professional of the roads is submitted. If there is already a charge among male truck drivers, the truck driver's aggravation is precisely in legitimizing his ability to work as he reaches "man's time."

The particularities of the work, the activities and the operating conditions of this and that sector must be carefully considered. In this regard, considering the work of the truck driver, even making the proper distinction between the understanding of labor processes derived from production and services, we can especially highlight two fundamental aspects, which today illustrate the work routine of these professionals and suggest to be related, at least less in part, to the formulation proposed by Toyotism, since there is a common thread in the aspect of the production of work-disciplinary mechanisms that are created in the factory, but which reproduce in the service sector, even if it is far from the control look of supervisors and by means of other rules that are incorporated into the work activity and cross the physical limits of the company to operate in different workspaces.

In this sense, there is a rupture, or rather a reordering of the fields of power whenever something changes from what was stipulated. The entry of women into the labor market and, recently, their occupation in works considered masculinized, lead us to the emergent production of another look at the unfolding of the phenomena. This understanding enables us to evaluate the most subtle manifestations of power that are disregarded in the readings of women truck driver activity, to understand the practices that are legitimized within this field and exert a significant power of transformation in the actions of the agents involved.

The inclusion of women in work composes what Antunes (2005, p. 47) calls the "(new) multifaceted character of work". In this perspective, there would be an overlapping of domestic and institutional work, "increasing the exploitation of the female contingent" (ANTUNES, 2005, p. 80). Work, socially constructed along with so many aspects of humanity, parallel to the domination of the masculine, dictated different forms of labor for men and women. First, the fact that women stay at home to take care of their children and, on the other hand, men dedicate themselves to work, has marked socially the gender of domination. We emphasize feminist discussions, which includes thinking about the identity that, after being revealed in its particularities, leaves us as an inheritance a permanent commitment to the interlocution of work. The new forms of being and being that produce other modes of socialization do not cease to belong to and reinsert themselves in the already wellknown structuring and hierarchical modes of production; now, however, they are again re-signified under other veils of power.

There are elements present in the game of powers that suggest an attempt by man to promote the maintenance of the "strategies of domination that underpin the binary construction of difference of the sexes" (VARIKAS, 1994, p. 67). Among them, however, we first highlight the production of violence against women as the main reproductive tool of exploitationdomination. Male power "crosses all social relations, it becomes objective, translating itself into hierarchical structures, into objects, into common sense" (SAFFIOTI, 2001, p. 120).

By this aspect, all gender research demands a critical exercise anchored in the transposition of legitimized models of power. These issues are guided by an invisible resistance in which everyday experiences - representations - are always thought from the point of view of class and gender, in an articulated way (SOUZA-LOBO, 2011). The author states that the positions are sexualized, since, for example, "male resistance is described as a power relation [in counterpart] to that of women as resistance, irresponsibility, lack of interest" (SOUZA-LOBO, 2011, p. 87).

In this way, we emphasize that, in the case of inequalities, it is precisely the sum of the evidence of exclusion that give the given phenomenon greater expressiveness within the social environment. That is, female truck drivers, although subject to gender discrimination, prejudice and, sometimes, harassment at work, for example, are far from leading the worst of inequality scenarios. There is a gap in Organizational Studies that should exchange for other elements such as class, race, ethnicity or even sexual orientation for the accumulation of capital, identifying precariousness at the intersection with the categories of gender, class, race, and ethnicity (BLAY, 2001; PISCITELLI, 2008; HIRATA, 2002, 2009, 2016; KERGOAT, 2009). However, the issue is not less important because there is a shift from women to masculinized work, which can not fail to be evidenced. 
In this sense, work is undeniably a central foundation in the production of subjectivity and, consequently, of psychic suffering, which must be seen together with a wide range of risks and their invisibilities. In addition to the risk of accidents, we understand that, at present, the risks follow in the sphere of the invisible - totally related to sociopsychological factors (SALVAGNI, 2012). At the same time, that risk is a constituent element of the subjectivity of workers, the personal experiences of the subject will compose their representation of the risk in the work and is specifically what is produced in this relation, aggravated by the processes of time, acceleration and other conditions of work. For this reason, it is essential to interlocal gender categories with work. The theoretical premises can no longer be seen without making an appropriation of what is specific to the work of the woman. This study sought to unveil the prominences that are accentuated in a perspective of domination when it comes to the work performed by the woman.

\section{FINAL CONSIDERATIONS}

The intention of dialoguing with different theoretical proposals, such as structuralism and postmodern theories of gender and identity, is to show that, if on the one hand the conceptions of alienation and domination at work postulated by Marxism remain current, on the other hand emerging the construction of a sociological thinking that accounts for the contingency of gender identity applied to this critical conception of the forms of labor relations. This analysis, therefore, contributes to the ongoing practice of administrative theories and practices, in order to encourage debates on labor and its intersections to take a look from Organizational Studies, especially at a time when social rights have been strongly threatened in Brazil.

As far as gender is concerned, it is indisputable that the questions concerning body, skeleton, and strength do not prevent the woman from carrying out the so-called masculinized activities. It is part of the discourse of common sense, if not reinforced in the scientific milieu, to emphasize the supposed male superiority not only with respect to dexterity or vigor but especially using physical force as an argument. In this way, women are part of social construction that has reinforced over time the idea that they are not able to perform certain activities under the justification of a physical disability. In a political sense, it is fundamental that this aspect of the physical conditions associated with the gender be rebounded, since it bases a series of prejudices and stops the actions of the women in front of professional perspectives. When they are surrounded by a speech of incapacity, women, in general, incorporate an invented truth that distances the multiple possibilities of being and being in social life. It is a fact that maternity causes a break in the activity of the woman regarding heavy service, but this event is momentary and should not intervene in construction work.

The non-place, the space of the itinerant, is marked by the place of the masculine. The woman, according to sexist gender roles, belongs to the house, nothing more. This place of passage, whose most common activities are connected to the means of transport, whether it be an airplane pilot, a sailor, a machinist, an oil worker or even a taxi driver, as well as a trucker, are those who suppose a detachment from the home, a disconnection from the routine orders of home or family care, which is well accepted socially when occupied by the male character.

A woman, therefore, when moving from home to work and living on a road of uncertainty, supposes to give up even her own image of the woman that has been attributed to her since she was a girl. That is, she assumes a gender shift, from what was foreshadowed to her, at the moment when she leaves the house and the notion of traditional family, even momentarily, to give priority to work. However, even if she plays the game of the masculine, assuming for herself conducts and norms that are part of the universe of which she wants to be part, nevertheless she constantly seeks, through her speeches and actions, to play a feminine, apparent role fragility and vanity, since these are the codes that were historically taught to seal. On the one hand, therefore, it marks what anyone else knows: that it is still a woman; On the other hand, it surrenders to the imminence of an environment charged by masculine senses, which it can not deny, it needs to dialogue to be accepted and assumes for itself, since work, in its essence, is ruled by dirt, physical strength and a certain strength that also belongs to the masculine. Thus, it has no other way than to mark with their codes, so that the work is done, not to be motive of debauchery and to show itself it's own overcoming. However, as the truck becomes a more truck, the masculinized labor trajectory will continue to create meaning for you, your job, your womanhood. In elaborating her identity with and on the road, she begins to perceive the world under other prisms: she sees an extension of the border between what she already knows of the world and what she has to know and, more than that, she explores herself in her limitations and possibilities. It considers itself, with all right, warrior of itself. 
As for the question of labor, it is clear that the insertion of women into a masculinized activity is not enough to change the logic of gender domination. It is a fact that there is boldness, a breaking of the social rule by the woman who is disposed to what we consider a dirty job, but this puts her in unequal dispositions regarding the roles of the feminine and masculine in society - as in any other profession.

It is appropriate to point out that the inclusion of women in typical masculinized activities, while demarcating a new job opportunity for the female public, broadening and reinforcing the struggle for equality in working conditions, also produces the creation of new relations of domination inherent to the ownership groups. This means that care must be taken with the apparent dilutions of gender-based social inequalities at work, since these, while showing important advances, also vehemently recreate new and no less severe forms of domination. In these lines, we see significant gaps in future studies on work and gender, which should be keen to uncover the new facets of oppression.

Moreover, regarding the traveler's place of passage, we consider that the anonymity and the solitude present in the activity of the truck tends to believe that it may not take care of the appearance in the absence of the researcher in the trips. That is, we assume that the researcher, due to the visit to the truck, may have stimulated in the trucks drivers certain accentuated caring practices. If this research interference did not happen, she would probably not be concerned on wearing makeup, but she does it to show herself more feminine since she supposes, as she is in an environment recognized as masculine, that she can be confused in the middle of it. More than that, she wants to stand out. She wants to show that she drives a truck, that she was able to announce a different way of doing her job and that she could paint lipstick on the canvas marked by misogyny.

Thus there is much to be done in political and academic terms that unveils the new faces of exploitation, domination and contemporary misogyny. We glimpse the truck drivers as protagonists of a confrontation with social norms. Beyond an adventurous way of working, side by side with the numerous road hazards, these women are helping to rethink the very conception of the feminine, reinforcing that the woman's place is where she wants. "By fostering the struggle for gender equality in the labor market, we question the heteronormative, sexist, and binary patterns that historically curtail the freedom of identities, and condemn them to live under the norm." 


\section{REFERENCES}

ANTUNES, R. O caracol e sua concha: ensaios sobre uma nova morfologia do trabalho. São Paulo: Boitempo, 2005.

ANTUNES, R. Desenhando a nova morfologia do trabalho: as múltiplas formas de degradação do trabalho. Revista Crítica de Ciências Sociais, n. 83, p. 19-34, 2008.

ANTUNES, R. Os modos de ser da informalidade: rumo a uma nova era da precarização estrutural do trabalho? Serviço Social \& Sociedade, n. 107, p. 405-419, 2011.

AUGÉ, M. Não lugares: introdução a uma antropologia da supermodernidade. Campinas: Papirus, 1994.

AUGÉ, M. O sentido dos outros. Petrópolis: Vozes, 1999.

BARDIN, L. Análise de conteúdo. Porto: Ed. 70, 1995.

BERGER, P. Perspectivas sociológicas: uma visão humanística. 4. ed. Petrópolis: Vozes, 1978.

BLAY, E. A. Um caminho ainda em construção: a igualdade de oportunidades para as mulheres. Revista USP, n. 49, p. 82-97, 2001.

BRAH, A. Diferença, diversidade, diferenciação. Cadernos Pagu, n. 26, p. 329-376, 2006.

CANCLINI, N. G. Culturas híbridas: estratégias para entrar e sair da modernidade. São Paulo: Edusp, 1997.

CARRIERI, A. P.; PAULA, A. P. P.; DAVEL, E. Identidade nas organizações: múltipla? fluida? autônoma? Organizações \& Sociedade, v. 15, n. 45, p. 127-144, 2008.

HALL, S. A identidade cultural na pós-modernidade. 4. ed. Rio de Janeiro: DP\&A, 2000a.

HALL, S. Quem precisa da identidade? In: SILVA, T. T. (Org.). Identidade e diferença: a perspectiva dos estudos culturais. Petrópolis: Vozes, 2000b. p. 103-133.

HALL, S. Da diáspora: identidades e mediações culturais. Belo Horizonte/Brasília, DF: Ed. UFMG/Unesco, 2003.

HIRATA, H. Globalização e divisão sexual do trabalho. Cadernos Pagu, n. 17-18, p. 139-156, 2002.

HIRATA, H. Por quem os sinos dobram? Globalização e divisão sexual do trabalho. In: TEIXEIRA, M. (Org.). Trabalho e cidadania ativa para as mulheres: desafios para as políticas públicas. São Paulo: Coordenadoria Especial da Mulher, 2003. p. 9-11.

HIRATA, H. A precarização e a divisão internacional e sexual do trabalho. Sociologias, v. 11, n. 21, p. 24-41, 2009.

HIRATA, H. Subjetividade e sexualidade no trabalho de cuidado. Cadernos Pagu, n. 46, p. 151-163, 2016.

HIRATA, H.; KERGOAT, D. Novas configurações da divisão sexual do trabalho. Cadernos de Pesquisa, v. 37, n. 132, p. 595-609, 2007.

HIRD, M. Sex, gender, and Science. Houndmills: Palgrave Macmillan, 2004.

KERGOAT, D. Divisão sexual do trabalho e relações sociais de sexo. In: HIRATA, H. et al. (Org.). Dicionário crítico do feminismo. São Paulo: Ed. Unesp, 2009. p. 67-75.

LOURO, G. L. Um corpo estranho: ensaios sobre a sexualidade e a teoria queer. Belo Horizonte: Autêntica, 2008.

NEFFA, J. C. Los paradigmas productivos taylorista y fordista y su crisis: una contribución a su estudio, desde el enfoque de la "Teoria de la Regulación". Buenos Aires: Lumen, 1998.

NICHOLSON, L. Interpretando o gênero. Revista Estudios Feministas, v. 8, n. 2, p. 8-41, 2000.

PISCITELLI, A. Interseccionalidades, categorias de articulação e experiências de migrantes brasileiras. Sociedade e Cultura, v. 11, n. 2, p. 263-274, 2008.

SAFFIOTI, H. I. B. Contribuições feministas para o estudo da violência de gênero. Cadernos Pagu, n. 16, p. 115-136, 2001.

SALVAGNI, J. Tempo, trabalho e risco: uma análise das temporalidades nas relações de trabalho. Confluências, v. 12, n. 1, p. 213-237, 2012.

SCOTT, J. W. O enigma da igualdade. Estudos Feministas, v. 13, n. 1, p. 11-30, 2005.

SILVA, T. T. Documentos de identidade: uma introdução às teorias de currículo. 3. ed. Belo Horizonte: Autêntica. 2011.

SOUZA-LOBO, E. A classe operária tem dois sexos: trabalho, dominação e resistência. São Paulo: Fundação Perseu Abramo, 2011.

VARIKAS, E. Gênero, experiência e subjetividade: a propósito do desacordo Tilly-Scott. Cadernos Pagu, n. 3, p. 63-84, 1994.

Julice Salvagni

ORCID: https://orcid.org/0000-0002-6334-0649

Ph.D. in Sociology from the Federal University of Rio Grande do Sul (UFRGS); Adjunct professor in the Department of Administrative Sciences at UFRGS,

Porto Alegre-RS, Brazil. E-mail: julice.salvagni@ufrgs.br 